\title{
Parallel Worlds: Cold War Division Space
}

\author{
SCOTT NEWTON
}

\section{Introduction: Division Space}

The Cold War brought into the world and the world of inter-state relations a novel kind of space, Division Space - really, a novel mode of spatialisation altogether. The double Germanies, the double Vietnams, the double Koreas, the double Berlins, and the double Chinas were split along the Cold War fault line itself. But that line was not merely a geological feature or a surveyor's or boundary commission's line of demarcation, not a 38th parallel or River Elbe. They were only the most spectacular instances of a new space of division of unprecedented scope and penetration, simultaneously jurisdictional (legal), geographic, demographic, political, cultural, economic and ultimately civilisational. The scale of division was adjustable and fractal: city, state, continent, globe. The World was henceforth Two Worlds in parallel and in contraposition, East and West, to be joined by a Third with decolonisation, but itself subject to the reigning spatialisation of doubling or splitting, at subnational, national, or continental scales.

In the Cold War East and West thus became far more than cardinal points denoting imagined cultural polarities as they had been in Orientalist discourse. They were not simply opposing spaces, geographic poles, but constituent of Division Space itself. Division Space was not simply an external theatre or field which international law would condition, constrain, enable or regulate but a deformation or transformation of the international legal field itself. For international law, Division Space amounted to more than just an application of established doctrines like state recognition or standard devices like international agreements. Division Space polarised the world, not in the simplistic strategic sense, but in the originary sense of electromagnetism - the induction across 
a field of a realignment of its constituent particles by application of a force. This realignment signalled a fundamental shift in previously taken-for-granted conditions of modern collective existence, identity, relations and norms. The world now existed in parallel, specular, rival versions or visions, a doubling and splitting that was not directly reflected in but refracted through the international order, fundamentally conditioning it. Division Space thus deformed the field of international law not merely and straightforwardly in respect of borders, juxtaposition and regulation but obliquely in respect of spaces, superposition and effects. The split in the human rights covenants and the rise of the Non-Aligned Movement are emphatically among its products.

\section{Parallel Universes}

The tropes of Cold War-era science fiction and comics are a particularly period-appropriate way of developing the phenomenology of Division Space. A classic comic book trope is that of parallel universes containing alternate versions of the same superheroes, worlds occupying the same space in different dimensions. They overlap but not in a simple physical way; they are not juxtaposed but superposed. In The Flash of Two Worlds, ${ }^{1}$ the titular superhero discovers the existence of another version of himself (the character's 1940s incarnation from comics' 'golden age') on Earth-Two, to be eventually populated (in the serial manner in which comics mythology is elaborated) with a teeming gallery of Earth-One alternates. Earth-One and Earth-Two stand in a specular relationship; they are distorted reflections of one another, with recognisably similar objects and persons, but altered and shifted out of reciprocal register, assuming different functions and playing different roles. Once the basic principle of parallelism had been established, it became subject to baroque variation in a multiverse imaginary. So for instance, 'Ultraman' was the supervillain counterpart of Superman on Earth-Three.

Parallel universes are separate but mutually accessible; they can open onto one another through portals and warps; they can bleed into one another. And sometimes they can collide and inter-penetrate, which gives rise to a classic comics multiverse crisis. ${ }^{2}$ Division Space is then

${ }^{1}$ Gardner Fox and Carmine Infantino, 'Flash of Two Worlds' in The Flash (DC Comics, September 1961) vol. 1, no. 123.

2 See, e.g., Marv Wolfman and George Perez, Crisis on Infinite Earths (DC Comics, 1985-6) vols. $1-12$. 
a matter of parallelism and inter-penetration and distinct versions of the same or similar things - like economic and political systems. Like modernities. Like futures. Like pasts. How do the enabling conditions for parallelism, the duplication, the correlative differences on a ground of similarity, arise in the first place? And how does one account for the relation between the parallel spaces?

In the world of law generally and the world of international law particularly, universes originate with the drawing of lines, the mapping of jurisdiction. Any jurisdiction establishes and frames or bounds a juridical space, a legal geography. That space can potentially attain world-dimensions, can seed a bubble universe, if the geographic conditions are propitious: national spaces certainly, but equally corporate and even carceral spaces - the Vereenigde Oost-Indische Compagnie in the eighteenth century or the gulag in the twentieth.

The enabling conditions for the regulatory field of international law thus necessarily include (although they cannot simply be reduced to) the territorial bounding of sovereign polities to begin with - the sovereign inside is constituted simultaneously with the anarchic-and-nowregulated inter-sovereign outside. ${ }^{3}$ International law originates and remains most at home in demarcating surfaces. That is, its line- and boundary-drawing cartography is topographic, literally, delineation of place. The stuff of international law is bounding jurisdictions. The 1945-6 territorial settlements (agreed in the Potsdam Protocol) in the wake of the World War which conditioned the Cold War and enabled Cold War Division Space had much in common with previous such settlements. Indeed, the cartographic and jurisdictional adjustments from 1945-7 were far less dramatic than those in 1918-22: Potsdam generated far greater transfers of populations than shifts in borders. ${ }^{4}$ Although international boundary settlements had divided jurisdictions before - even as long ago as Westphalia itself, when the Spanish Netherlands was effectively partitioned between North (United Provinces) and South (Flanders) - they had never before resulted in the signature division of division space: alternate versions of one recognisably or definably common space, parallel worlds engendering specular realities.

${ }^{3}$ Such a topographic account of international legal origins is itself ideological and contestable, asserting the primacy of the juridical over the social and political, but is adopted here heuristically. See Benno Teschke, The Myth of 1648 (Verso, 2003).

${ }^{4}$ Tony Judt, Postwar: A History of Europe since 1945 (Penguin, 2006) 27. 


\section{Superpowers and Superprojects}

How does one account for both the paralleling, specular qualities of Division Space and simultaneously its universal dimensions? Division Space presented alternate realities for good and cogent reasons having to do with the particular character of the protagonists, the Mighty Opposites. It was the Union of Soviet Socialist Republics and the United States of America that represented the supreme instantiations of Cold War parallel universes, of Earth-One and Earth-Two. They alone nurtured parallel universalising ambitions as rival capitals of modernity or ends of history. They were not just twin superpowers but twin superprojects: each conceived itself and had been so constituted, in 1924 and 1787, as an elaborately articulated and institutionalised microcosm, a utopian blueprint which could be rolled out to the rest of the world.

The United States and the Union of Republics (with the rhyming of their chosen self-glorifying planetary and parallel names) were unlike all states, all empires, and all Great Powers at the time or previously, not because they were Mighty Opposites (that is, superpowers), but because they were superprojects and superorders and superimaginaries, mutually constitutive and mutually exclusive: reciprocal radical alterities. Their newly acquired capacity for mutual (and general) physical annihilation was only the material correlate of their symbolic capacity for mutual displacement or replacement as orders. A superpower is merely a quantitatively new international legal subject, a great Great Power. A superorder is a qualitatively new subject of international law; indeed, it is a microcosmic international order in itself, a synecdoche of world government.

The propaganda posters of the day trumpeted the incomparable virtues of the good life, American-style and the good life, Soviet-style. The superiority of the American Dream or the Soviet Dream was perhaps most famously debated between Richard Nixon and Nikita Khrushchev in a mock kitchen at a cultural exchange exhibition in Moscow in 1959: a case of the bleeding between the worlds. These were rival dreamworlds or mass utopias in Susan Buck-Morss' characterisation. ${ }^{5}$ They each set out to realise mass political desire and to bring forth mass society, to fashion a novus ordo saeculorum for ordinary women and men, for the demos, the citizenry. They were twin Enlightenment Projects conceived along

${ }^{5}$ Susan Buck-Morss, Dreamworld and Catastrophe: The Passing of Mass Utopia in East and West (MIT Press, 2000). 
radically divergent but kindred premises. The Bolsheviks and the American Founders' Heirs each invented industrial modernity but in rival, diametric versions which logically and ideologically could not coexist or co-occupy the same space and hence created a new kind of impossible space, Division Space. They presented dimensionally superposed alternative societies and alternative histories, parallel presents but also parallel pasts and parallel futures, and parallel trajectories from the one to the other. ${ }^{6}$ And they both had cosmic destinies as the only spacefaring nations.

The advent of any two superpowers would undoubtedly have exercised deforming effects on an international legal field which was configured to reflect and serve the interests of a plurality of great powers fringed by a multitude of lesser powers. ${ }^{7}$ But these rival dreamworlds were not just superpowers but rival superorders as well, each comprehensively institutionalised and articulated, fully kitted-out with distinctive parallel social, economic, cultural and governance institutions - fully realised instantiations of twentieth century modernities. Owing to the diversity of populations - the one immigrant, the other autochthonous - their territorial reach and demographic heterogeneity, and their singular selfconceit as vanguard or maximally advanced polities, they were each a world or universe unto itself. A critical post-Cold War perspective should not confer on them any straightforward equivalence, ${ }^{8}$ but still, precisely in their multinational or melting-pot, radically social or radically civil specular variants, these were model world states, microcosms, continentally realised versions of a societal order aspirationally global in scope: superorders, anticipating a future global order. They could be

${ }^{6}$ Correlative to the images in billboard and posters were the parallel World's Fairs, ВДНХ (VDNKh) in Moscow, the 1950s Soviet theme park of the Achievements of the People's Economy and the 1964 World's Fair in New York, a celebration of post-war American material prosperity and cultural modernity. Indeed, its temerity notwithstanding (a convention of such fairs), 'World's Fair' was plausible and pardonable as a name for such an event at this Augustan moment, the crest of the American Century.

${ }^{7}$ Gerry Simpson, Great Powers and Outlaw States: Unequal Sovereigns in the International Legal Order (Cambridge University Press, 2004).

8 Arguably, the Soviet project was the more innovative and radical, expressly enshrining and institutionalising multinationalism and multiculturalism in its fantastically baroque scheme of ethno-territorial federalism and cultural regulation through juridical ethnicity, as, of course, revolutionising political economy by expropriating the expropriators and socialising the means of production. The American mass utopia, by contrast, was premised on an amalgamated, self-constructed nation, drawn from all others, even ultimately those it had enslaved or reduced and quarantined, and the democratisation (individualisation) of capital itself. 
scaled up to planetary scope and institutionally remake and remodel the globe each in their own respective image. The United States of the World and the World Union of Soviet Republics. World Government EarthOne and World Government Earth-Two.

\section{Topography and Topology: Divided Space and Division Space}

It is customary to think of Cold War space as divided or separated space, created in this topographic or cartographic fashion. As Divided Space it is represented most starkly by its fault lines, like the boundary of the Soviet sector in Berlin or the 38th parallel in Korea. Borders obviously make divided space. However, Division Space in the sense proposed here is not merely topographic but topological. Topology is the set of mathematical permutations to which spaces can be subject whilst retaining identity - convolution, inversion, deformation, folding. It is the distinctive topology of Cold War Division Space that makes possible its bleeding, inter-penetrability and interpermeability. How might jurisdictions be defined or conceived topologically rather than merely topographically or cartographically? China Miéville's novel The City and The City, ${ }^{9}$ which in this sense is perhaps the definitive jurisdictional Cold War novel, suggests an answer.

Two cities, Beszel and Ul Qoma, share the same locality: they literally coexist, co-occupy a common space. Some roads are allocated to one or the other of the two, black or white, but other roads and even structures are 'cross-hatched' in the novel's conceit. They belong to both cities and are shared between them - though the citizens of each of the cities are not permitted to recognise or interact with those of the other even as they pass them in the shared roads. They must 'unsee' those who share their physical space but not their jurisdictional space. Cold War Division Space is not just The City and The City but 'The State and The State', 'The Continent and The Continent' and ultimately 'The World and The World'. And there is a kind of fractal geometry operating across all these different scales of Division Space, such that the same spatial relations are found at each: the municipal East and West (Berlin) and the continental East and

9 China Miéville, The City and The City (Tor Books, 2009). 


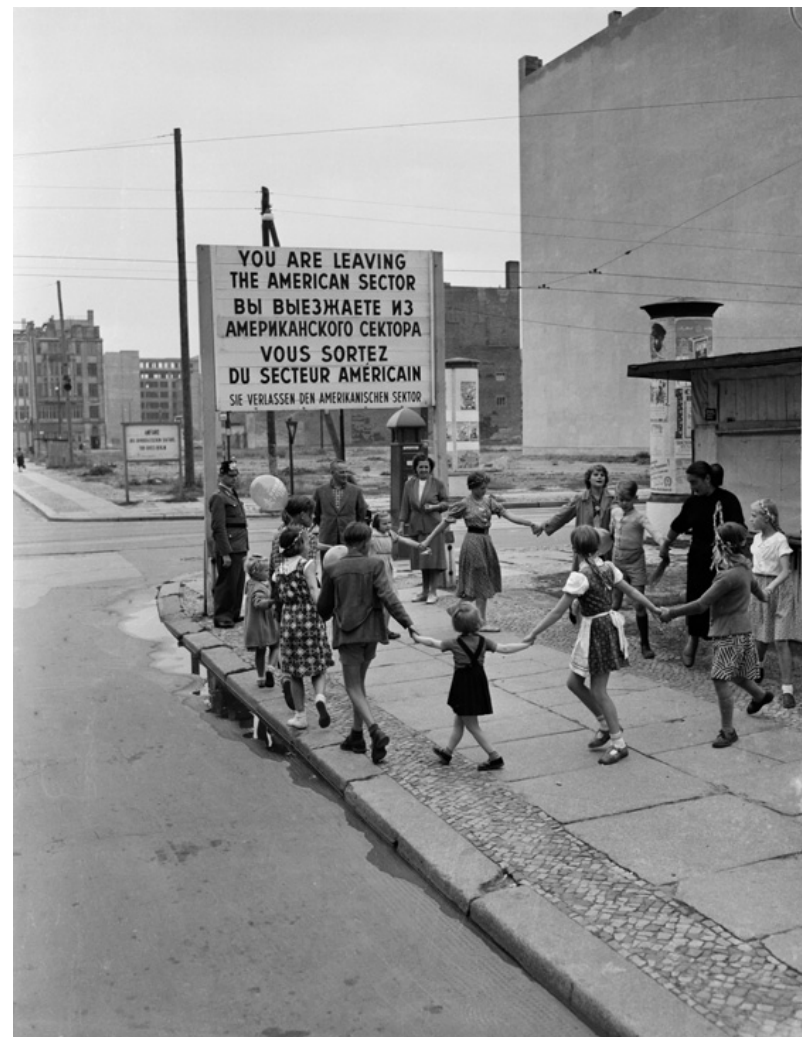

Figure 6.1 Division Space Berlin (before the Wall)

West (Eastern - formerly 'Central' - Europe and Western Europe) are configured or contoured in a parallel way.

The supreme incarnation of The City and The City, and no doubt the inspiration for the novel, was of course Berlin and Berlin. Ironically, occupied Berlin with the four sectors open in the 1950s furnishes a better illustration of Division Space (The City and the City) than Berlin after the erection of the Wall in 1961, at which point the sectors were closed, at the culmination (and resolution) of the Berlin crisis. The barrier-Divided Space of the Wall era is less compelling and, in a way, less emblematic of the Cold War than the Division Space of Berlin in the preceding decade when free movement across the sectors was possible. In 1950s Division Berlin, but not in post-1961 Divided Berlin, the parallel worlds bled into one another: Berlin was cross-hatched before it was black and white. Occupied Berlin was of course quadripartite, pursuant to the Agreement 
between the Allies on the occupation zones in Germany (London, 26 July 1945), but the siting of the capital of the German Democratic Republic in the Soviet zone upon its creation in 1949 effectively partitioned Berlin into an 'East Berlin' and a 'West Berlin' as its constituent Other.

\section{Partition}

Just prior to the commencement of the Cold War (which might be dated for this purpose to the Berlin Airlift), and in geographic contexts apparently remote from its European heartland if not its political polarisation, the logic of Division Space had already been manifested in a schematic way. At the dawn of decolonisation in 1947, the creation of parallel jurisdictions out of common colonial space was the premise and object of Partition. There were two grand contemporaneous instances - one successful, at least in its own terms, the other not. In the case of Palestine, the colonial power was subject to an international mandate, and a General Assembly resolution adopted the partition plan - a plan, as the world well knows, which was not acceptable to one of the parties, and the implementation of which was mooted by the ensuing hostilities, population expulsion and yet another post-war settlement, a truce line which became with time an international boundary. ${ }^{10}$

In the case of India, the same colonial power was of course just exercising its own authority in decolonising by adopting the Independence of India Act, thereby partitioning the Raj between two successor dominions, and partitioning three provinces along the Radcliffe Line between them in the process. Hence the international legal dimension appears secondary. But notwithstanding the absence of an expressly Cold War angle, and as a glaring exception to the uti possidetis rule which would govern later episodes of decolonisation (and as decolonisation proceeded enable the global inflation of Division Space, as argued below), these two cases in some strange way already exhibit what comes to be the hallmark of Cold War Division Space, the doubling or parallelism: two versions of India, Hindu and Muslim. And an imagined or projected two versions of Palestine, Arab and Jewish. If the 1947 Partitions of India and Palestine adumbrate Cold War spatialisation in a kind of straightforward topographic sense (at least in the case

${ }^{10}$ United Nations Department of Public Information, 'The United Nations and the Question of Palestine', UN Doc. DPI/2157/Rev.1 (November 2002). 
of the Radcliffe Line, with the significant exception of Kashmir; the Palestine plan rather recalls Beszel and Ul Qoma in its intricacy), its mature logic is a kind of complex and multidimensional, topological not merely topographical, Partition, with black, white and cross-hatched zones reproduced fractally at multiple jurisdictional levels.

The initial instances of Cold War partition proper - Berlin, Germany, Korea, Vietnam - similarly began as Divided Space and resulted in Division Space, shifting from the topographic to the topological. The 38th parallel bisecting the truce village of Panmunjom is a good instance of a line of international legal significance - in this case, a truce line which becomes an international boundary - immediately establishing a Divided Space but ultimately engendering the parallelism of Division Space. The Division Space engendered by the 38th parallel, the jurisdictional demarcation based on a cartographic convention, is exemplified by Seoul and Pyongyang. These are duplicate national capitals, geographically proximate but dimensionally remote from one another, summoned into being initially by a line. Distorted specular reflections, parallel places produced by a parallel of latitude, topological permutations on the basis of topographic separation, alternative versions of a state, nation, capital city, society and reality. Korea Earth-One and Korea Earth-Two.

\section{Juxtaposition and Regulation/Mediation by International Law}

Those classical instances of Cold War partition betokened a similarly 'classical' international regulatory response in the form of a memorialised conflict settlement. The partition in each case is pursuant to such a settlement (which need not, and only exceptionally did, assume the form of a binding treaty): the 1945 Occupation of Germany Agreement (uniquely among these cases an agreement among allied occupying powers); the 1953 Korea Armistice Agreement (respecting the line separating the 1945 Soviet and US occupations); and the 1954 Geneva Accords. ${ }^{11}$ In each of them jurisdictional claims or prerogatives were juxtaposed; they confronted one another across a line demarcated to

${ }^{11}$ Agreement on the Cessation of Hostilities in Viet Nam (signed and entered into force 20 July 1954); Agreement on the Cessation of Hostilities in Cambodia (signed and entered into force 20 July 1954); Agreement on the Cessation of Hostilities in Laos (signed and entered into force 20 July 1954); Final Declaration of the Geneva Conference on the Problem of Restoring Peace in Indo-China (21 July 1954). 
adjudicate them. In one way or another those classic Cold War partition cases were aspects of what could be considered the series of settlements after the defeat of the Axis powers, codicils to Potsdam, the December 1945 Moscow Conference of Foreign Ministers ${ }^{12}$ or the peace treaties with Japan. ${ }^{13}$ Later instances of the patrolling or policing of Cold War Division Space (although not in the context of a partition or conflict settlement) also demonstrated this international regulatory mode: for example, the 1962 agreements on missile removals from Cuba and Turkey that resolved the October crisis. ${ }^{14}$

Which is to note that multilateral regulation of Division Space and mediation of the conflicts generative of it was perhaps the default or primary mode of the relation of international law to the Cold War and international law's engagement with it. International conflict settlements by treaty or lesser instrument bear only an accidental, contingent or external relation to Division Space. They address boundaries, not the Division Space itself that those boundaries condition and enable; they mediate juxtaposition, not superposition. Both the Geneva Conference of 1954 and the Security Council meetings of October 1962 (when US Ambassador Adlai Stevenson famously flung the gauntlet of $\mathrm{U} 2$ reconnaissance photos of the Cuban missile sites) are again classic theatres of this regulatory and mediative mode of international legal engagement.

\section{Superposition and Deformation/Doubling of International Law}

But neither the episodic moments of high diplomatic drama and confrontation, the emblematic Cold War Crises - the naval quarantine in the Cuban coastal waters and the tanks facing one another at Checkpoint Charlie - nor the resolutions of those crises in the council chambers, neither the regulatory challenges nor the regulatory

12 Soviet-Anglo-American Communiqué (27 December 1945), Interim Meeting of Foreign Ministers of the United States, the United Kingdom and the Union of Soviet Socialist Republics, Moscow, 16-26 December 1945.

13 Treaty of Peace with Japan, signed 8 September 1951, 136 UNTS 45 (entered into force 28 April 1952).

${ }^{14}$ Concluded as secret diplomatic protocols. The only formal agreement to emerge from the October crisis was the telephone hotline agreement: 'Memorandum of Understanding between the United States of America and the Union of Soviet Socialist Republics Regarding the Establishment of a Direct Communications Link', signed 20 June 1963, II C 20 (entered into force 20 June 1963). 


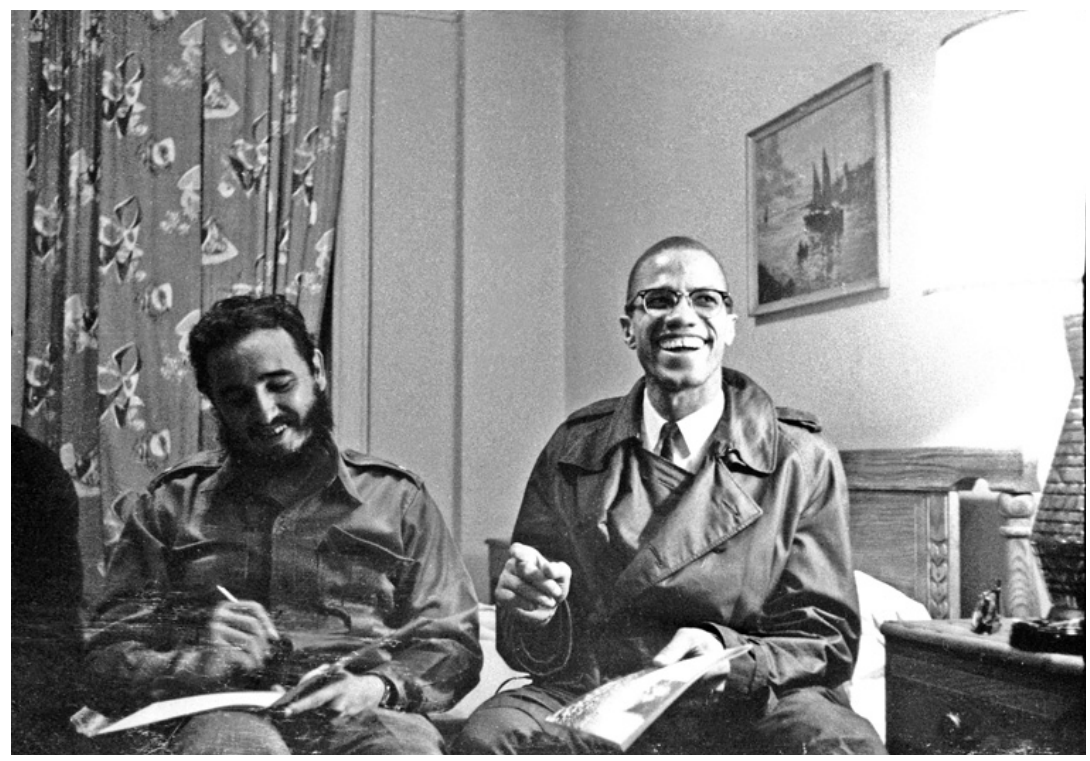

Figure 6.2 Division Space Harlem, 1960: Malcolm X and Fidel Castro meet at the Hotel Theresa

Source: REUTERS / Desmond Boylan

responses, neither the occasions nor the operations of formal international legal intervention, reveal the distinctive international legal dimensions of Cold War Division Space. Those can only be appreciated in Division Space proper, from within its topologically folded and doubled complexities, in contexts of superposition not juxtaposition, in the way international legal arrangements themselves facilitated the folding and doubling and the way international law itself came to be folded and doubled. For international legal norms, processes, logic, and practices themselves were subject to Division Spatialisation, and their wonted coordinates were displaced and replaced by those of Division Space.

In September 1960, Fidel Castro entertained Malcolm X and Nikita Khrushchev in his suite at the St Theresa Hotel at 125th St and 7th Avenue. Harlem at this conjuncture was in an emphatic way Cold War Division Space, where parallel worlds bled into one another, both enabled by international law (the 1947 UN Headquarters Agreement), and exercising transformative effects on it. Here is the strange case of an internal opponent of the American state (Malcolm) meeting convivially with a soon-to-be external opponent or enemy (Fidel), and then of that external enemy meeting exuberantly and 
defiantly with external enemy number one, all on American home ground - although not entirely, since they met by choice in the capital of African America, which was not only not Washington, but not (diplomatic or downtown) New York either (a manifestation of America's homegrown division space, literally black, white and cross-hatched). There could be no more unheimlich moment, and unheimlich was of the essence of Division Space.

General Assembly Resolution 2200 of the 21st session, in 1966, ${ }^{15}$ adopted the international human rights covenants and opened them for ratification. But the General Assembly adopted them in twin versions, separate instruments for parallel categories of rights. This partition or dédoublement of an initially unitary declaration is a Cold War spatialisation of international standard-setting itself, a deformation of normative space. These are mirror instruments, one asserting the primacy of the social field for the subject of rights, the other the primacy of the civil. Parallel, specular conceptions of rights. Human Rights Earth-One and Human Rights Earth-Two. The Covenant for the Free World, enshrining liberty as the cardinal Enlightenment value. And the Covenant for the Fair World, enshrining equality as the cardinal Enlightenment value.

The distortions or topological twists of Division Space did not only manifest themselves in so obvious a fashion in the very corpus of treaty law itself. In the enunciations of international institutions, one finds an analogous parallelism and mirroring. In 1978, UNESCO commissioned and published an authoritative treatise on the state of the social and human sciences, a kind of summa studia humanitatis, with an international institutional imprimatur. ${ }^{16}$ It demonstrated how Division Space structured knowledge itself, scholarship and science, it was inside subjectivities and constitutive of them as well as outside in the world at large. In the second volume, the section on 'Legal Science ${ }^{\text {,17 }}$ was fissured into East and West, with principal sections devoted not to 'Civil Law' and 'Common Law' but to 'Western Countries' and 'Socialist

${ }^{15}$ International Covenant on Economic, Social and Cultural Rights, International Covenant on Civil and Political Rights and Optional Protocol to the International Covenant on Civil and Political Rights, GA Res 2200, UN GAOR, 3rd Comm, 21st sess, 1496th plen mtg, UN Doc. A/RES/2200(XXI) (16 December 1966).

16 Jacques Havet (ed.), Main Trends of Research in the Social and Human Sciences, Part Two (Mouton Publishers/UNESCO, 1978).

17 Victor Knapp (ed.), 'Legal Science' in Jacques Havet (ed.), Main Trends of Research in the Social and Human Sciences, Part Two (Mouton Publishers/UNESCO, 1978) vol. 2, section 3 , ch. VI. 
Countries'. 'Philosophy ${ }^{18}$ was similarly doubled, seriatim, such that continental and analytic accounts of the philosophies of action, language and the historical sciences, of social and political philosophy and of philosophical logic were necessarily shadowed by Soviet or Marxist accounts. Human Sciences Earth-One and Human Sciences Earth-Two.

\section{Decolonisation Division Space}

With decolonisation, Cold War Division Space expanded like an inflaton field to encompass the globe. The colonial powers' formal withdrawal and disengagement from the (economically and politically, albeit not militarily) occupied South opened a new hemispheric market, field and arena for the contest between the parallel modernities. Decolonisation space was congenitally Division Space. Colonies and empires had become a notorious liability in this contestation of modernities, much as slavery had become a century earlier. The USSR weaponised self-determination, ${ }^{19}$ but so for similar strategic and ideological reasons did the US: the one as a champion of defensive nationalism, subaltern nationalism, and as the shining example of socialist multiple self-determination in one country; the other as the originator of post-European, melting pot, civic nationalism and as the Ur-example of colonial auto-liberation.

Decolonisation for the most part obeyed the uti possidetis principle, and the territorial integrity of colonial jurisdictions was carried over into the post-colonial states. But because decolonisation became a privileged theatre for the grand East-West strategic contest, postcolonial and developing states became national departments of Division Space. Sometimes the national liberation movements themselves were split or doubled, riven by internal cleavage (Congo, India); sometimes the cleavages arose in post-independence politics (Jamaica); sometimes the post-colonial states aligned with East or West, institutionally and/or strategically (Zaire, Tanzania, Ghana, Ethiopia). In other cases, proxy civil wars raged: two would-be Angolas and Mozambiques, never carried through to the point of duplicate parallel sovereignties, instead eternally contesting a single space rather than splitting it. Occasionally

18 Paul Ricoeur (ed.), 'Philosophy' in Jacques Havet (ed.), Main Trends of Research in the Social and Human Sciences, Part Two (Mouton Publishers/UNESCO, 1978) vol. 2, section 3 , chs. VII and VIII.

19 See Bill Bowring, The Degradation of the International Legal Order?: The Rehabilitation of Law and the Possibility of Politics (Routledge-Cavendish, 2008) ch. 1. 
partition arose as an accident of differential colonial history, as international legal accident or contingency rather than international legal technique or device. The two Yemens, theirs and ours, resulting from the presence of the Aden protectorate in the Yemeni south, but resembling the other cases of Cold War splitting or doubling in yielding alternative versions of a Yemeni space.

Decolonisation Division Space was subject to international legal regulation and mediation in the same way as Division Space elsewhere. Thus Congolese Prime Minister Patrice Lumumba and UN Secretary-General Dag Hammarskjöld were among the principal actors in a fairly straightforward exercise of international intervention in and mediation of a regional conflict. The skulduggery and black ops to which they both fell victim the same fateful year, although classic nocturnal Cold Warfare, only point to the conventional nature of the daylight multilateral diplomacy.

\section{Development Division Space}

The Non-Aligned Conference in $1961,{ }^{20}$ by contrast, is another example of an effect of Division Space on international law rather than merely a response of international law to a problem or a provocation, an occasion for regulatory intervention. Non-Alignment is an attempt to assert the primacy of a North-South Axis over the East-West axis structuring Division Space. But Non-Alignment is not NonSpatialisation. Far from escaping Cold War spatialisation, the NonAligned Movement ('NAM') was produced by it and informed by it, was itself an artefact of Division Space. But it captured a significant further nuance or fold of that Division Space - not the one-off (or serial one-offs) of decolonisation, but the processes of 'development' which colonialism was understood to have thwarted or distorted or deferred. Viewed from the present vantage point, three decades after the end of the Cold War, Development Division Space seems to have produced the profoundest transformation of the international legal order, torquing its cardinal axis.

But Development Division Space was in its origins pre-eminently a Cold War space. Each of the superorders, insofar as it was

${ }^{20}$ Belgrade Declaration of Non-Aligned Countries (6 September 1961), 1st Summit Conference of Heads of State or Government of the Non-Aligned Movement, http://cns.miis.edu/nam/ documents/Official_Document/1st_Summit_FD_Belgrade_Declaration_1961.pdf. 
simultaneously a superproject, had a diachronic as well as a synchronic predicate. Each posited a trajectory, an élan vital. They had described, and they now prescribed, alternative modernisation processes, not just modernities. Alternative developmentalisms. Alternative linearities. John F. Kennedy brought the Alliance for Progress to Caracas in 1961, the massive US development assistance push to save the hemisphere from revolution and reassert the Monroe Doctrine of the inviolability of the Americas. The Cuban revolution represented a bleed of socialist EarthTwo space into capitalist Earth-One space on a hemispheric scale. The US foreign assistance engine went into overdrive to contain the bleed, close off the dimensional warp, forestall the cataclysmic collision of the parallel worlds. But Latin American space was now incontrovertibly Division Space, whatever the outcome.

For if the US saw development as the privileged means of preventing the displacement of Earth-One by Earth-Two, the USSR saw it as the privileged means to ensure that displacement. The Soviets, too, embarked on comprehensive economic assistance schemes in the Global South, not in Cuba alone (sending Cuban youth for training in the USSR and multiple Soviet agricultural and industrial consultants in the other direction), but throughout the Middle East and North Africa, East and West Africa, and South Asia. ${ }^{21}$

Thus development itself, as an interventionist project of the already developed world, became a kind of Cold War artefact or product, a manifestation of Division Space in bilateral and multilateral policy and regulation - the development agencies and banks, the Bretton Woods institutions (which the socialist states had mostly disdained to join) which came anomalously to be bankers and economic regulatory authorities for the Third World. Development as an external, exogenous political project was thus conceived and executed in two rival versions, foreign-directed and assisted socialist modernisation against foreign-directed and assisted capitalist modernisation. Duelling development projects. Development Earth-One. Development Earth-Two.

On 1 May 1974, the annual Red Square festivities celebrating labour in its courageous struggle with capital proceeded with customary fanfare. The UN General Assembly adopted the Declaration on the Establishment of a New International Economic $\operatorname{Order}^{22}$ the very

${ }^{21}$ Gu Guan-Fu, 'Soviet Aid to the Third World: An Analysis of Its Strategy' (1983) XXXV(1) Soviet Studies 71.

22 Declaration on the Establishment of a New International Economic Order, GA Res 3201, UN GAOR, 6th sess, Agenda Item 7, UN Doc. A/RES/S-6/320 (1 May 1974). 
same day. Two symbolically tethered events, an international legal moment produced by Division Space itself, emerging out of it. An international legal moment which challenged neo-colonial political economy, leading after an interval of a dozen years to the Declaration on the Right to Development ${ }^{23}$ - the international economic law of a former era, seeking to dethrone rather than enthrone Capital like the successor neo-liberal version. It reinterpreted and reimagined the North-South Axis through the East-West Axis of Division Space. It was a call for the end of the 500-year economic occupation of the Global South, a challenge to the hegemony of the North mounted on the basis of the critique from the East.

It was precisely in this sense that the Non-Aligned Movement was produced in and by Division Space. Frantz Fanon has earned his due and few would now contest that colonial Liberation meant liberation from the forced choice between the modernities on offer - the inspiration of the NAM and all the multiple strategies and movements of insistence on the primacy of South-North difference. Nonetheless, the original anti-colonial movement, as opposed to the later post-colonial analysis, was grounded in the critique of political economy rather than the critique of culture and race. The repudiation of the imperial order was the repudiation of the European world system and of the long march of colonising capital, which had colonised its natal European spaces before or as it colonised overseas non-European spaces. ${ }^{24}$ Division Space torqued the South-North Axis and demonstrated a kind of rotational symmetry by mapping West onto North and East onto South. Not only did decolonisation unfold across and through Division Space, but colonisation itself as historical process was retrospectively transformed by Division Space. And so was the establishment of the international order and the law of nations. ${ }^{25}$ Parallel world histories for the parallel worlds. On Earth-One 500 years of the global

23 Declaration on the Right to Development, GA Res 41/128, UN GAOR, 97th plen mtg, UN Doc. A/RES/41/128 (4 December 1986).

${ }^{24}$ A long-established tenet of World Systems Theory. See, e.g., Jason Moore, "Amsterdam is Standing on Norway" Part I: The Alchemy of Capital, Empire and Nature in the Diaspora of Silver, 1545-1648' (2010) 10 Journal of Agrarian Change 33; Jason Moore, "Amsterdam is Standing on Norway" Part II: The Global North Atlantic in the Ecological Revolution of the Long Seventeenth Century' (2010) 10 Journal of Agrarian Change 188.

25 Antony Anghie, Imperialism, Sovereignty and the Making of International Law (Cambridge University Press, 2007). 
spread of civilisation and progress. On Earth-Two 500 years of domination and exploitation. And from 1 May 1974, prospective parallel international orders. International Economic Law Earth-One. International Economic Law Earth-Two.

\section{Conclusion: Division Space, Undead and Deathless}

Now, long after the cessation of Cold hostilities and the disaggregation of one of the protagonists, Division Space seems to endure in two primary forms, one undead, the other deathless. The phenomenon of jurisdictional doubling or splitting, although perhaps the most spectacular manifestation of Division Space, has proved far from the most momentous for international law. Nonetheless, it has proved stubbornly enduring.

Partition and partition logic were present already in 1947 and outside an explicitly Cold War confrontation. Later, as national liberation struggles gathered steam, jurisdictional splitting or partition typically occurred when those struggles escalated into proxy wars or armed conflicts with intervention by one or both of the Mighty Opposites, which eventuated in a stalemate - Korea and Vietnam being clear examples. Jurisdictional splitting ensued when neither parallel world was capable of fully displacing the other, so they remained juxtaposed and only incompletely or partially overlapping or superposed in the simple form of Division Space.

Partition of existing jurisdictions, jurisdictional splitting, is obviously dependent on the existence of those jurisdictions in the first place, as noted in the introduction above (law creates spaces - and worlds - by fixing jurisdictions). They came into being by a kind of antecedent, originary partition - the establishment of colonies and the fixing of colonial boundaries. The Berlin West Africa Conference of $1884-5^{26}$ was a partition exercise which constituted or recognised jurisdictions in the first place. So was Moscow 1922-4 (and the years thereafter) when the Union of Soviet Socialist Republics was established

26

General Act of the Berlin Conference, 26 February 1885, C 4361 1885, in Edward Hertslet, The Map of Africa by Treaty 3rd ed. (HMSO, 1909) vol. 2, 128, 468; R. J. Gavin and J. A. Betley, The Scramble for Africa: Documents on the Berlin West African Conference and Related Subjects 1884-1885 (Ibadan University Press, 1973) 288. See Matthew Craven, 'Between Law and History: The Berlin Conference of 1884-1885 and the Logic of Free Trade' (2015) 3 London Review of International Law 31. 
and its first Constitution adopted ${ }^{27}$ and the then-Commissar of Nationalities set to the protracted process of 'national delimitation', partitioning the Romanov Empire and constituting or reconstituting ethnoterritorial jurisdictions - subnational ones this time, federal autonomies, Soviet Socialist Republics like Georgia as well as autonomous republics, provinces and areas. In both cases of course, the multilateral Berlin conference and Stalin's one-man conference, it was not only jurisdictions at stake; collective identities, nations, the selves of self-determination, were constituted or constructed at the same time. This inter- and intra-imperial partitioning supplied a kind of substrate or predicate for later Cold War division spatialisation over the course of decolonisation.

It has also provided a substrate or predicate for post-Cold War or neo-Cold War division spatialisation. The several post-Soviet statelets (Abkhazia, Transnistria, South Ossetia, Nagorno-Karabakh) have been recognised by no one save the other statelets and Moscow (and Venezuela and Vanuatu, among a very few others). The principal four all represent former Soviet-era autonomies. ${ }^{28}$ Setting aside for a moment the complex dynamics of national, cultural and strategic politics across post-Soviet space that generated the conflicts that in turn generated the statelets, one poses here the question of the strange afterlife of Cold War Division Space, its 'undead' state. These remnants and relicts of Division Space no longer figure in a cosmic context with existential stakes, an ongoing multiverse crisis, a collision of parallel worlds, but in a more classic context of Great Power rivalry and clashing spheres of interest - defying successful international legal regulation but still conditioned by it, as witness their near-universal non-recognition on the one hand and the various stalled or abortive internationally sponsored efforts at mediation and resolution of the underlying conflicts on the other.

The advent of the post-Soviet statelets might be understood as the ironic subjection to Division Space logic of the deferred decolonisation of the last incarnation of the Romanov Empire itself. In any event it represents an uncanny recapitulation and internalisation (internal to the ex-USSR) of Cold War partition, just as the EU eastern borders

27 Treaty of the Creation of the Union of Socialist Soviet Republics (29 December 1922); Constitution of the Union of Socialist Soviet Republics (January 1924).

28 Their number has swelled thanks to the Ukrainian hostilities and the appearance of the Donetsk People's Republic, not to mention the annexation of Crimea as a Subject of the Russian Federation. 
have come now arguably to demarcate a new seismic fault, shifting the East (and extending the West) further east but still setting it off. The spatialising (and specifically juridically and jurisdictionally spatialising) Cold War appears to have survived the temporal Cold War. Division Space haunts us still. But beyond the undead cases, it might survive in a more politically useful and potentially emancipatory form as well.

Granted, the multiverse crisis has apparently been resolved, with the collapse of the bloc, the ascendancy of neo-liberal governance, and the seemingly inexorable global convergence onto liberal market democracy, Superorder Earth-One, the New World Order. ${ }^{29}$ Earth-One has fully displaced Earth-Two, save for remnants, relicts and margins: the last sad pockets of alternative futurity after the end of the Cold War, whether largely rhetorical and ceremonial like Vietnam and China, or recalcitrant and defiant like North Korea and perhaps Cuba, or sui generis and Bolivarian like Venezuela. And of course, the persistence of jurisdictional partition in Georgia, Azerbaijan and elsewhere across the Russian 'near abroad'. Still, whether currently represented by Moscow, Caracas or Beijing, fresh deviations from/challenges to a world order now putatively embodying or valorising institutional convergence (liberal market democracy) might well have recourse to a reanimation of East-West Division Space.

Yet Division Space haunts in other, more promising ways as well: the renewed salience of the New International Economic Order and the Right to Development, ${ }^{30}$ the fissures and splits evident everywhere across the Sustainable Development Goals notwithstanding their apparent suturing of Division Space, the multiple flavours of counter-hegemonic globalisation and transnational action networks, ${ }^{31}$ the kaleidoscope of emancipatory strategies and histories and futures. That is the deathless rather than undead form of contemporary Division Space. Beyond the relicts and the margins, Division Space is also still detectable; parallel universes continue to bleed into this one, episodically, sporadically, recurrently, unexpectedly. In the wake of the binary superorders and the binary superprojects, alternative international orders are now

29 Susan Marks, The Riddle of All Constitutions (Cambridge University Press, 2000).

30 Anne Orford, 'Globalization and the Right to Development' in Philip Alston (ed.), Peoples' Rights (Oxford University Press, 2001) 127.

31 Boaventura de Sousa Santos and César A. Rodríguez-Garavito (eds.), Law and Globalization from Below: Towards a Cosmopolitan Legality (Cambridge University Press, 2004). 
imaginable, alternative projects are now practicable. Another world is possible. Other worlds are possible. Cold War Division Space brought on a multiverse crisis, but it has opened the multiverse. Beyond Earth-One and Earth-Two might lie (as they do in the comics multiverse) all the other Earths, the series of infinite possible parallel universes. 